\title{
Increased aortic stiffness in patients with Type 1 (insulin-dependent) diabetes mellitus
}

\author{
H. Oxlund ${ }^{1}$, L. M. Rasmussen ${ }^{2}$, T.T.Andreassen ${ }^{1}$ and L. Heickendorff ${ }^{3}$ \\ ${ }^{1}$ Department of Connective Tissue Biology, Institute of Anatomy, University of Aarhus, \\ ${ }^{2}$ Research Laboratory for Biochemical Pathology, Institute of Pathology and \\ ${ }^{3}$ Department of Clinical Chemistry, Kommunehospitalet, Aarhus, Denmark
}

\begin{abstract}
Summary. The biomechanical properties of aortic samples from patients with Type 1 (insulin-dependent) diabetes mellitus and age- and sex-matched control subjects were analysed using a materials testing machine. The specimens were prepared from tissue outside areas of visible atherosclerosis in order to discriminate between primary Type 1 diabetic alterations in the aortae and secondary changes due to increased atherosclerosis. We paid special attention to the correction of biomechanical parameters for differences in wall thickness and registration of specimen length values. In the Type 1 diabetic aortae a marked reduction was found in the extensibility and an increase in their stiffness. The reduced extensibility was correlated significantly to the duration of Type 1
\end{abstract}

diabetes. The pronounced alterations in the mechanical properties could not be explained by the increase in the wall thickness which was observed among the Type 1 diabetic patients and the alterations could not be correlated to the grade of atherosclerosis in the thoracic aorta. The results of the present study, therefore, strongly suggest that Type 1 diabetic patients develop alterations in the arterial connective tissue independent of the presence of atherosclerosis. Such primary alterations in the vessel wall may play a role in the pathogenesis of large vessel disease among these patients.

Key words: Type 1 (insulin-dependent) diabetes mellitus, biomechanics, diabetic macrovascular disease, collagen.
The high frequency of macrovascular disease among diabetic patients is well known $[1,2]$. The pathogenesis of the diabetic large vessel disease, however, is only poorly understood.

Several studies have reported alterations in arterial stiffness among diabetic patients. Both the measuring of pulse wave velocity [3-5] and recent investigations using ultrasound techniques, have shown increased arterial stiffness among diabetic patients $[6,7]$. These studies, however, have not been able to discriminate between primary alterations in the arteries of diabetic patients and secondary changes due to increased atherosclerosis. Moreover, these in vivo measurements are confounded by the influence of blood pressure and do not, therefore, solely indicate alterations in vessel wall composition. Several investigations point towards primary alterations in the connective tissue in the arteries of diabetic patients. Medial calcification $[8,9]$ and accumulation of periodic acid Schiff (PAS)-positive substance $[10,11]$ have been described in diabetic arteries independent of the presence of atherosclerotic plaques. These primary diabetic alterations could, therefore, be expected to alter the mechanical parameters of the arteries.
The aim of the present study was to analyse the biomechanical properties of aortic samples taken at the post mortem examination from Type 1 diabetic patients. In all samples circumferential strip specimens were prepared from tissue outside areas of visible atherosclerosis. In the mechanical analyses we paid special attention to corrections of the biomechanical parameters for differences in wall thickness.

\section{Material and methods}

Samples of human mid-thoracic descending aortae were obtained from 27 post mortem examinations: 9 Type 1 (insulin-dependent) diabetic subjects and 18 age- and sex-matched control subjects. No differences were found in weight, height and body mass index (BMI = weight in $\mathrm{kg} /$ height in $\mathrm{m}^{2}$ ) between the Type 1 diabetic and control subjects. Table 1 gives age, sex, occurrence of hypertension, duration of Type 1 diabetes and area of visible intimal lesions in the descending thoracic aorta for each Type 1 diabetic subject and Table 2 the mean values for the group of Type 1 diabetic patients and the control group. Patients treated for hypertension and patients with more than one blood pressure measurement above 140/100 were considered hypertensive. The aortic samples were taken within $40 \mathrm{~h}$ post mortem. The aortae were opened longitudinally, and the circumference was measured between the 8th and 10th intercostal artery. The percentage of the surface area of the vessel covered with macroscopi- 
Table 1. Clinical details and mechanical parameters of thoracic aorta specimens from subjects with Type 1 (insulin-dependent) diabetes mellitus

\begin{tabular}{|c|c|c|c|c|c|c|c|c|c|c|}
\hline $\begin{array}{l}\text { Patient } \\
\text { number }\end{array}$ & $\begin{array}{l}\text { Age } \\
\text { (years) }\end{array}$ & Sex & $\begin{array}{l}\text { Hyperten- } \\
\text { sion }\end{array}$ & $\begin{array}{l}\text { Area of } \\
\text { intimal } \\
\text { lesions } \\
(\%)\end{array}$ & $\begin{array}{l}\text { Duration } \\
\text { of } \\
\text { diabetes } \\
\text { (years) }\end{array}$ & $\begin{array}{l}\text { Aortic } \\
\text { circum- } \\
\text { ference } \\
(\mathrm{cm})\end{array}$ & $\begin{array}{l}\text { Wall } \\
\text { thickness } \\
\text { (mm) }\end{array}$ & $\begin{array}{l}\text { Ultimate } \\
\text { extensi- } \\
\text { bility } \\
(\%)\end{array}$ & $\begin{array}{l}\text { Max. } \\
\text { stiffness } \\
\tan \beta \\
(\mathrm{N})\end{array}$ & $\begin{array}{l}\text { Max. } \\
\text { stiffness } \\
\tan \alpha \\
\left(\mathrm{N} / \mathrm{mm}^{2}\right)\end{array}$ \\
\hline 2 & 65 & M & No & 15.9 & 28 & 5.6 & 1.93 & 36 & 37 & 9.6 \\
\hline 3 & 42 & $\mathrm{M}$ & Yes & 54.5 & 27 & 4.9 & 1.90 & 36 & 67 & 9.7 \\
\hline 4 & 58 & $\mathrm{~F}$ & No & 10.8 & 27 & 5.8 & 1.67 & 28 & 46 & 7.6 \\
\hline 7 & 59 & $F$ & No & 10.1 & 33 & 4.9 & 1.94 & 18 & 60 & 8.3 \\
\hline 8 & 67 & $\mathbf{M}$ & Yes & 9.7 & 36 & 6.5 & 1.65 & 15 & 74 & 11.1 \\
\hline 9 & 73 & $\mathrm{~F}$ & No & 50.8 & 58 & 5.6 & 2.04 & 10 & 111 & 13.6 \\
\hline
\end{tabular}

$\mathrm{N}$ : newton

Table 2. Biomechanical parameters of thoracic aorta specimens from Type ( (insulin-dependent) diabetic subjects and non-diabetic control subjects matched with respect to age and sex

\begin{tabular}{|c|c|c|c|c|c|c|c|c|c|c|}
\hline & $\begin{array}{l}\text { Number } \\
\text { of } \\
\text { patients }\end{array}$ & $\begin{array}{l}\text { Age } \\
\text { (years) }\end{array}$ & $\begin{array}{l}\text { Aortic } \\
\text { circum- } \\
\text { ference } \\
\text { (cm) }\end{array}$ & $\begin{array}{l}\text { Wall } \\
\text { thickness } \\
(\mathrm{mm})\end{array}$ & $\begin{array}{l}\text { Area of } \\
\text { intimal } \\
\text { lesions } \\
(\%)\end{array}$ & $\begin{array}{l}\text { Ultimate } \\
\text { extensi- } \\
\text { bility } \\
(\%)\end{array}$ & $\begin{array}{l}\text { Maximum } \\
\text { load } \\
\text { (N) }\end{array}$ & $\begin{array}{l}\text { Maximum } \\
\text { stiffness } \\
\tan \beta \\
(\mathrm{N})\end{array}$ & $\begin{array}{l}\text { Maximum } \\
\text { stress } \\
\left(\mathrm{N} / \mathrm{mm}^{2}\right)\end{array}$ & $\begin{array}{l}\text { Maximum } \\
\text { stiffness } \\
\tan \alpha \\
\left(\mathrm{N} / \mathrm{mm}^{2}\right)\end{array}$ \\
\hline $\begin{array}{l}\text { Control } \\
\text { subjects }\end{array}$ & 18 & $\begin{array}{l}57.9 \\
(2.3)\end{array}$ & $\begin{array}{c}5.9 \\
(0.2)\end{array}$ & $\begin{array}{c}1.42 \\
(0.04)\end{array}$ & $\begin{array}{l}23.5 \\
(4.1)\end{array}$ & $\begin{array}{l}43.4 \\
(1.5)\end{array}$ & $\begin{array}{c}7.77 \\
(0.49)\end{array}$ & $\begin{array}{l}37.6 \\
(2.6)\end{array}$ & $\begin{array}{c}1.49 \\
(0.08)\end{array}$ & $\begin{array}{c}7.18 \\
(0.42)\end{array}$ \\
\hline
\end{tabular}

Mean values with SEM in parenthesis. N: newton.

a $2 p<0.001$ vs control group

cally visible atheroslerotic plaques was measured by point-counting with a grid placed over the vessels. Points falling over fibrous plaques and lesions exhibiting ulcerations, aneurysms or mural thrombosis were counted as atherosclerotic points. The vessel was then washed in Tris-buffered saline (Tris (hydroxymethyl) aminomethan $2.5 \mathrm{mmol} / \mathrm{l}$, $\left.\mathrm{NaCl} 154 \mathrm{mmol} / \mathrm{l}, \mathrm{KCl} 6 \mathrm{mmol} / \mathrm{l}, \mathrm{CaCl}_{2} 2 \mathrm{mmol} / \mathrm{l}, \mathrm{pH} 7.4\right)$ and stored at $-70^{\circ} \mathrm{C}$. Before testing the tissue was thawed at $37^{\circ} \mathrm{C}$.

\section{Preparation of specimens for the biomechanical analyses}

The aortic samples were laid flat on a piece of cardboard. Most of the adventitia was carefully removed without stretching the intima-media preparation. The adventitia does not contribute to the mechanical properties of aortic specimens as analysed by the present method [12]. When a strip of aortic tissue is strained, the media fails before the adventitia is fully extended, confirmed by pilot studies on the present material. The adventitia was removed in order to obtain correct measures of specimen thickness and in order to get standardized intima-media samples for the subsequent biochemical analyses. The aortic sample was frozen to about $-5^{\circ} \mathrm{C}$, and five circumferential strip specimens, $4 \mathrm{~mm}$ wide, were punched out from each aortic sample. The strips were prepared from areas of the tissue without macroscopically visible atherosclerotic plaques. The specimens were immersed in Tris-buffered saline at $4^{\circ} \mathrm{C}$ until testing.

Biomechanical analyses were performed as described in detail elsewhere [12-14]. Registration of specimen lengths was done using a modification of the method of Mohan and Melvin [15]. The specimens were mounted in two clamps with a jaw space of $10 \mathrm{~mm}$. Two dots of ink were lightly printed on the initimal side, $5.5 \mathrm{~mm}$ apart (Fig.1). The clamps with the specimen were mounted in a materials testing machine (Instron 1270, Instron Ltd., High Wycombe, UK). The tests were conducted at room temperature, and Tris-buffered saline $\left(21^{\circ} \mathrm{C}\right.$, pH 7.4) was sprayed on the specimen. Each specimen was preconditioned before the actual test by repeated loading and unloading five times in order to straighten the connective tissue fibers, obtaining a re- producible load-strain relationship at small load values, important for definition of the initial length of the specimen. In these loading phases, the specimen was stretched until a load value of 1.8 newton was recorded. The initial length of the specimen was determined after this preconditioning. The initial length was defined as the distance between the two dots $\left(1_{0}\right)$ at that moment when the specimen was stretched to a load of 0.2 newton. The dimensions of the specimen were recorded photographically. The front and side of the specimen were photographed simultaneously by using two cameras at right angles to the specimen (Fig. 1). The load and deformation values were registered continuously by the load-cell and extensometer of the materials testing machine. The signals were fed to a X-Y-recorder and registered as load-deformation curves. The photographic registration of the specimen was marked on the load-deformation curve. Every time a picture was taken, the flash was used, and then produced a

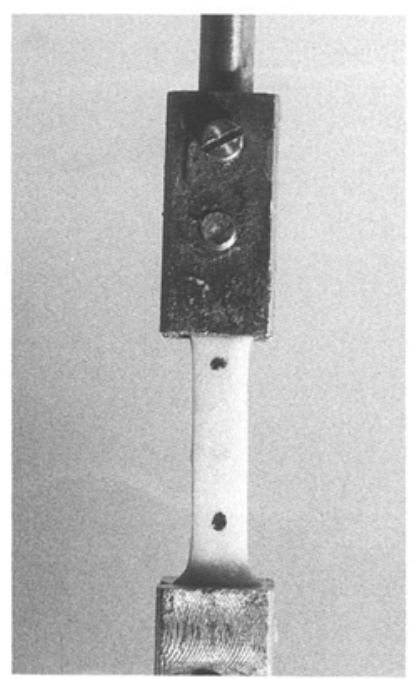

Fig. 1. Photographic record of initial specimen length, wall thickness and width of the specimen 


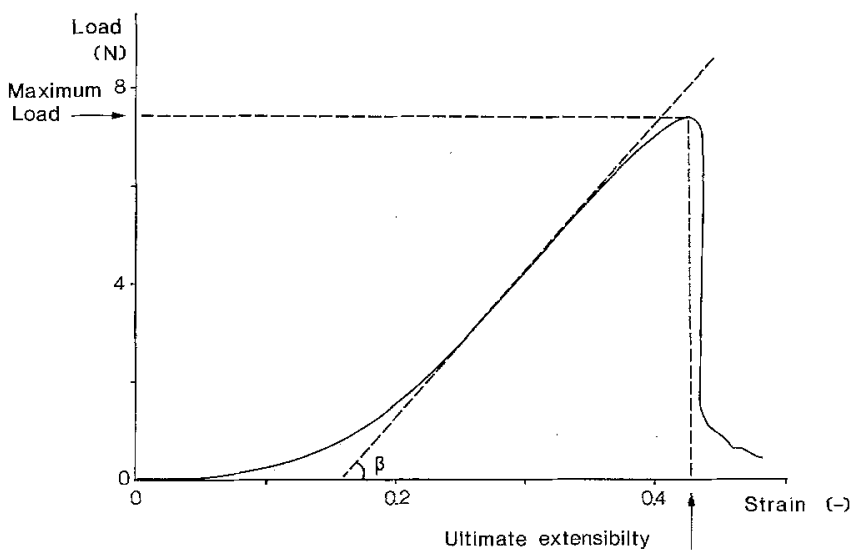

Fig. 2. Circumferential strips of thoracic aortae were analysed by means of a materials testing machine. The diagram gives the typical load-strain relationship and the parameters of ultimate extensibility, maximum load and tangent of the angle $\beta$ giving the maximum stiffness of the specimen. $\mathrm{N}=$ newton

small voltage spike which was registered by the X-Y-recorder and marked on the load-deformation curve.

After preconditioning and definition of the initial length and dimensions of the specimen, it was loaded at a constant deformation rate of $85.7 \mathrm{~mm}$ per min until rupture. The resulting load-deformation curves were read into a computer by a digitizer. The data were transformed to load-strain and stress-strain curves. Stress values were calculated by dividing the load values by the cross-sectional area (wall thickness $\mathrm{x}$ width) of each specimen measured from the photographs taken, when the specimen was stretched to a load value of 0.2 newton, i.e. initial length. The strain values of each specimen were calculated from the photographic films by dividing the increase in the distance $\left(1-l_{0}\right)$ between the ink dots by the initial distance $\left(l_{0}\right)$ between the ink dots when the specimen was stretched to a load value of 0.2 newton. From the load-strain curves (Fig. 2) the following parameters were calculated:

Ultimate extensibility: Strain at maximum load $(\mathrm{mm} / \mathrm{mm})$, in Tables 1 and 2 expressed as a percentage of the initial distance.

Maximum load: Strength of the specimens expressed in newton.

Maximum stiffness: The starting point and ending point of the approximately linear part of the curves were marked, and a line was drawn through these two points. The tangent of the angle between this line and the abscissa was the $\tan \beta$, expressing the slope of the approximately linear part of the curves expressed in newton.

From the stress-strain curves the following parameters were calculated:

Maximum stress: Tensile strength expressed in newton $/ \mathrm{mm}^{2}$.

Maximum stiffness: Slope of the stress-strain curves, $\tan \alpha$, expressed in newton $/ \mathrm{mm}^{2}$.

\section{Statistical analysis}

Mean values and SEM for each group are given in Table 2. Statistical analyses were made by employing the non-paired Wilcoxon's two sample test and Spearman's rank correlation [16]. $2 p<0.05$ was considered statistically significant.

\section{Results}

No significant differences were found between the Type 1 diabetic and control groups regarding area of visible intimal lesions and circumferences of aortae
(Table 2). In the Type 1 diabetic group, 5 patients had suffered from hypertension and 4 had been normotensive. In the control group, 5 patients had been hypertensive, 11 normotensive and for 2 patients it was not possible to extract sufficient information from the patient files concerning their blood pressure. The thickness of the aortic wall of Type 1 diabetic subjects was increased compared to that of the control subjects (Table 2). A typical load-strain relationship of a circumferential strip of thoracic aorta is given in Figure 2. It has a pronounced toe-part, which is followed by a linear part that leads to the breaking point. The parameters of ultimate extensibility, maximum load and the tangent of the angle giving the maximum stiffness of the strip were calculated from the curve. For the Type 1 diabetic subjects the ultimate extensibility of the strips was reduced and values of maximum stiffness $(\tan \beta)$ markedly increased compared to the controls (Table 2 , Fig.3). No differences were found for the values of maximum load. When the load values were corrected for differences in the thickness of the strips, giving the stress values, we still found an increased maximum stiffness $(\tan \alpha)$. These pronounced differences in the
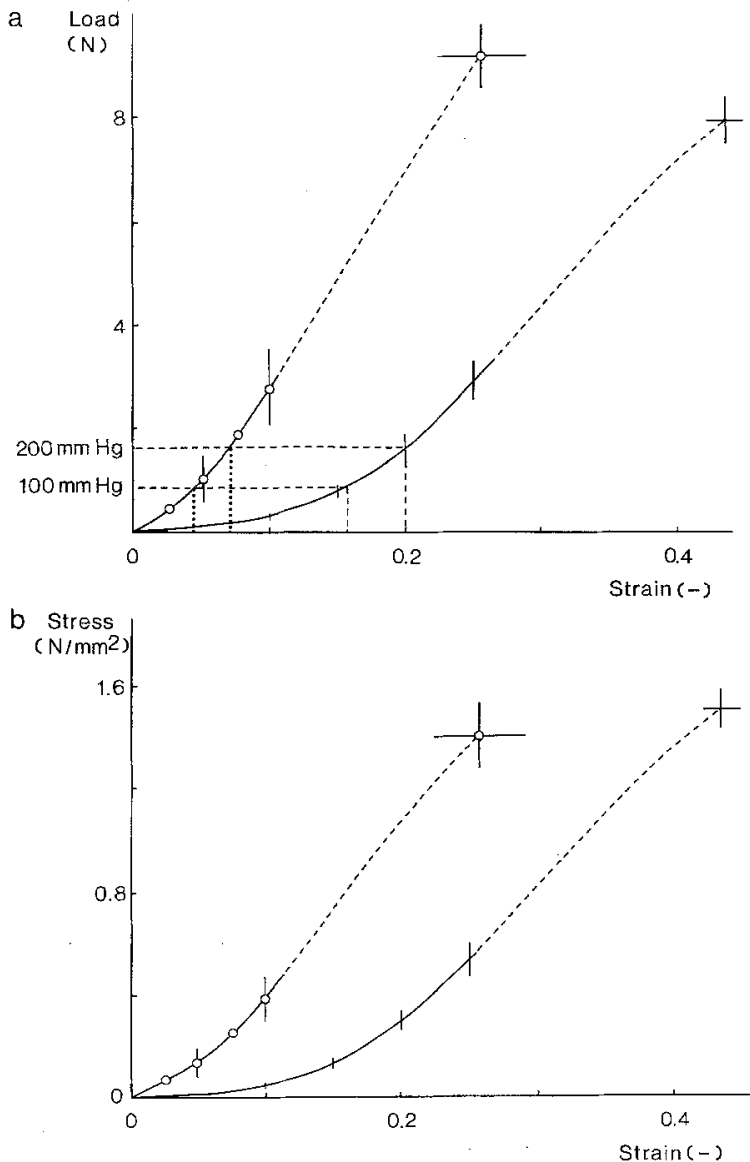

Fig. 3 a and b. Load-strain (a) and stress-strain (b) diagrams of thoracic aorta specimens from 9 Type 1 (insulin-dependent) diabetic subjects $(-\mathrm{O}-\mathrm{O}-\mathrm{O}-)$ and 18 age- and sex-matched control subjects (—). SEM values are given by bars. The forces exerted by blood pressures corresponding to 100 and $200 \mathrm{~mm} \mathrm{Hg}$ are marked by broken lines on the load-strain curve of the control group in a. $N=$ newton 


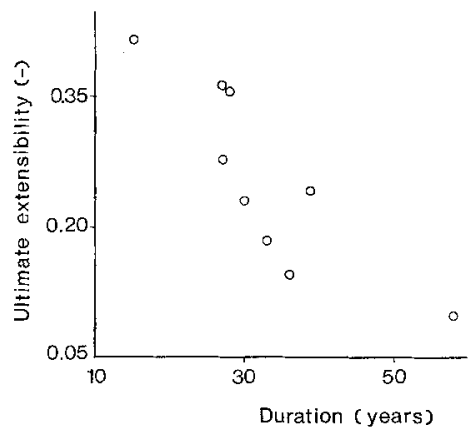

Fig.4. Correlation between the ultimate extensibility of thoracic aorta specimens and duration of the diabetes of 9 Type 1 (insulin-dependent) diabetic subjects. Spearman's $\mathrm{R}=-0.86,2 p<0.05$

load-strain and stress-strain relationships of aortic samples from the Type 1 diabetic and control groups, also in the region of the curves corresponding to a blood pressure of $100 \mathrm{~mm} \mathrm{Hg}$, are shown in Figure 3.

A significant correlation was found between the reduction in extensibility of the Type 1 diabetic aortic specimens and the duration of the diabetes (Spearman's $\mathrm{R}=-0.87,2 p<0.05$ ) (Fig. 4). No influence of hypertension was found on the biomechanical parameters of the Type 1 diabetic group. No significant correlation was found between the reduction in extensibility and the age of the Type 1 diabetic patients. No correlations were found between other biomechanical parameters and age, BMI, degree of atherosclerosis and post mortem time, either in the Type 1 diabetic individuals or in the control subjects.

\section{Discussion}

The method used for analysis of the static biomechanical properties of aortic samples is an in vitro method, and it primarily describes the biomechanical properties of the collagen and elastin fibrous network of the aortic samples $[13-15,17,18]$. The method is suitable when analysing the influence of quantitative and qualitative alterations of the tissue components on the biomechanical properties of tissues [19]. We found a marked reduction in the extensibility and an increase in the maximum stiffness of the aortic wall in Type 1 diabetic patients. These pronounced alterations could not be explained solely by the increased wall thickness or by the presence of atherosclerotic plaques. A significant correlation was found between the reduced extensibility of the aortic samples and the duration of the Type 1 diabetes, and this correlation could not solely be explained as an agerelated alteration in the mechanical properties of the aortae. Our data are in agreement with the investigations on pulse wave velocity $[3,5]$, echocardiographic studies of arterial diameters [6,7] and increased thickness of the arterial wall in patients with diabetes [20].

The marked reduction in the extensibility and increase in the stiffness of the diabetic aortic specimens were also found in the part of the load-strain curve which corresponds to physiological blood pressures (Fig.3). This suggests that the distensibility of the diabetic aortae in vivo might be impaired in comparison with that of age- and sex-matched control subjects, resulting in increased haemodynamic strain on the aortic wall accelerating atherogenesis [21], consistent with observations of an increased degree of atherosclerosis in coronary arteries and aortae of patients with diabetes [1, 22].

One could speculate if the occurrence of hypertension plays a role in the reduced extensibility of the Type 1 diabetic samples. Five of 9 Type 1 diabetic subjects had suffered from hypertension vs 5 of 16 control subjects. Within the Type 1 diabetic group, however, the ultimate extensibility of samples from subjects who had suffered from hypertension did not differ from that of the subjects who had been normotensive. Therefore, the reduced extensibility of the Type 1 diabetic samples is not merely vascular alterations induced by hypertension.

In previous studies on experimental rats with diabetes induced by streptozotocin treatment, we found reduced amounts of hydroxyprolin $\left(\mu \mathrm{g}\right.$ per $\left.\mathrm{mm}^{2}\right)$ and elastin ( $\mu \mathrm{g}$ per $\left.\mathrm{mm}^{2}\right)$, increased glycation of collagen, but no increase in the stiffness of the aortic tissue [23]. When the parameters of strength were corrected for the decrease in dry weight, however, the maximum stress value of the aortic tissue was found to be increased. Formation of reactive carbonyl compounds from the glucosyllysines, resulting in stabile cross-links between the collagen molecules, was suggested as an explanation of these changes in the strength of the aortae. The duration of the experimental diabetes in the rats was 3 months, which is a relatively short period compared to the duration of the diabetic state of the Type 1 diabetic subjects in the present study. This might explain the disparity between the sparse effect of the diabetic state on the mechanical properties of the rat aortae and the marked effects on the mechanical properties of aortic samples from human Type 1 diabetic subjects.

It is important to emphasize that the described differences in the mechanical parameters of the present study are obtained in areas of the vessel wall without plaques, indicating that substantial changes in the connective tissue of arteries occur in diabetes independent of the presence or absence of atherosclerotic plaques. The evaluation of atherosclerotic plaques was made on a macroscopical basis, and early lesions might, therefore, have been overlooked. However, the absence of correlation between the degree of atherosclerosis and the obtained biomechanical parameters adds evidence to the statement that the increased stiffness occurs independently of the presence of atherosclerosis. This is in agreement with earlier described alterations in arteries from diabetic patients, where changes have been found both in areas of the vessel with and without plaques. 
Thus, quantitative histochemical investigations of the extramural coronary arteries from patients with Type 2 (non-insulin-dependent) diabetes have shown that these patients accumulate a PAS-positive substance in the tunica media $[10,11]$. In addition, investigations using soft $\mathrm{X}$-rays have shown that diabetic patients have more incidents of arterial calcification, especially in the tunica media [8,9]. Also, increased glycation of proteins has been described in the aortae and coronary arteries of patients with diabetes [24]. It has been proposed that increased non-enzymatic glycation of proteins, especially collagens and elastin, may play a role in the formation of advanced glycation end products, i. e. stabile crosslinks between the collagen molecules, resulting in biomechanically rigid structures $[23,25,28]$, which is supported by in vitro studies on collagen incubated with glucose [29-32]. Whether the accumulation of extracellular matrix components, deposition of calcium, increased non-enzymatic glycation of proteins and formation of advanced glycation end products or other factors in the diabetic arteries are the primary cause of the described biomechanical alterations remains to be elucidated.

Acknowledgements. This investigation was supported by the Danish Diabetic Association, Kong Christian Den Tiendes Foundation and the NOVO Foundation. The authors wish to thank Mr. N. Kappel for skilled technical assistance and Mrs. Aa. Young for linguistic tevision.

\section{References}

1. Kannel WP, McGee DL (1979) Diabetes and cardiovascular disease. The Framingham Study. J Am Med Assoc 241: 2035-2038

2. Keen H (1987) Macrovascular disease in diabetes mellitus. In: Andreani D, Crepaldi G, Di Mario U, Pozza G (eds) Diabetic complications: early diagnosis and treatment. John Wiley \& Sons, London, pp 3-12

3. Woolam GL, Schnur PL, Vallbona C, Hoff HE (1962) The pulse wave velocity as an early indicator of atherosclerosis in diabetic subjects. Circulation 25: 533-539

4. Pillsbury III HC, Hung W, Kyle MC, Freis ED (1974) Fundamentals of clinical cardiology: arterial pulse waves and velocity and systolic time intervals in diabetic children. Am Heart J 87: 783-790

5. Hoeks APG, Ruissen CM, Hick P, Reneman RS (1985) Transcutaneous detection of relative changes in artery diameter. Ultrasound Med Biol 11: 51-59

6. Thordarson H, Thorgeirsson G, Helgason T (1986) Aortic stiffness in insulin-dependent diabetics: an echocardiographic study. Diabetic Med 3: 449-454

7. Christensen T, Neubauer B (1987) Arterial wall stiffness in insulindependent diabetes mellitus. Acta Radiol 28: 207-209

8. Ferrier TM (1964) Radiologically demonstrable arterial calcification in diabetes mellitus. Aust Ann Med 13: 222-228

9. Neubauer B (1971) A quantitative study of peripheral arterial calcification and glucose tolerance in elderly diabetics and nondiabetics. Diabetologia 7: 409-413

10. Ledet $T$ (1968) Histological and histochemical changes in the coronary arteries of old diabetic patients. Diabetologia 4: 268-272

11. Dybdahl H, Ledet T (1987) Diabetic macroangiopathy. Quantitative histopathological studies of the extramural coronary arteries from Type 2 (non-insulin-dependent) diabetic patients. Diabetologia 30: $882-886$
12. Oxlund $H(1984)$ Changes in connective tissues during corticotrophin and corticosteroid treatment. Biomechanical and biochemical studies on muscle tendon, skin and aorta in experimental animals. Thesis, University of Aarhus. Dan Med Bull 31: $187-206$

13. Oxlund $H$ (1980) Changes in the biomechanical properties of skin and aorta induced by corticotrophin treatment. Acta Endocrinol 94: $132-137$

14. Oxlund H, Andreassen TT (1980) The roles of hyaluronic acid, collagen and elastin in the mechanical properties of connective tissue. $\mathrm{J}$ Anat 4: 611-620

15. Mohan D, Melvin JW (1982) Failure properties of passive human aortic tissue. I - uniaxial tension tests. J Biomechan 15: 887-902

16. Sokal RR, Rohlf FJ (1981) Biometry. WH Freeman, San Francisco

17. Dobrin PB (1978) Mechanical properties of arteries. Phys Rev 58: $397-460$

18. Fung YC (1981) Biomechanics. Mechanical properties of living tissues. Springer, New York, pp 261-301

19. Oxlund $H$ (1986) Relationships between the biomechanical properties, composition and molecular structure of connective tissues. Conn Tissue Res 15: 65-72

20. Christensen T, Neubauer B (1988) Internal diameter of common femoral artery in patients with insulin dependent diabetes mellitus. Acta Radiol Diagnosis 29: 423-425

21. McMillan DE (1981) Physical factors important in the development of atherosclerosis in diabetes. Diabetes 30 (Suppl 2): 97-104

22. Robertson WB, Strong JP (1968) Atherosclerosis in persons with hypertension and diabetes mellitus. Lab Invest 18: 538 -551

23. Andreassen TT, Oxlund $H$ (1987) Changes in collagen and elastin of the rat aorta induced by experimental diabetes and food restriction. Acta Endocrinol 115: 338-344

24. Vogt BW, Schleicher ED, Wieland OH (1982) $\varepsilon$-amino-lysinebound glucose in human tissues obtained at autopsy. Increase in diabetes mellitus. Diabetes 31: 1123-1127

25. Andreassen TT, Seyer-Hansen K, Bailey AJ (1981) Thermal stability, mechanical properties and reducible cross-links of rat tail tendon in experimental diabetes. Biochim Biophys Acta 677: 313-317

26. Monnier VM, Cerami A (1982) Non-enzymatic glycosylation and browning of proteins in diabetes. Clin Endocrinol Metab 10: $431-452$

27. Monnier VM, Kohn RR, Cerami A (1984) Accelerated age-related browning of human collagen in diabetes mellitus. Proc Natl Acad Sci USA 81: 583-587

28. Brownlee M, Cerami A, Vlassara H (1988) Advanced glycosylation end products in tissue and the biochemical basis of diabetic complications. N Engl J Med 318: 1315-1321

29. Kohn RR, Cerami A, Monnier VM (1984) Collagen aging in vitro by nonenzymatic glycosylation and browning. Diabetes $33 ; 57-59$

30. Yue DK, McLennan S, Handelsman DJ, Delbridge L, Reeve T, Turtle JR (1984) The effect of salicylates on nonenzymatic glycolylation and thermal stability of collagen in diabetic rats. Diabetes 33: 745-751

31. Andreassen TT, Oxlund $H$ (1985) Thermal stability of collagen in relation to non-enzymatic glycosylation and browning in vitro. Diabetologia 28: 687-691

32. Andreassen TT, Oxlund H, Danielsen CC (1988) The influence of non-enzymatic glycosylation and formation of fluorescent reaction products on the mechanical properties of -rat tail tendons. Connect Tissue Res 17: 1-9

Received: 10 March 1989

and in revised form: 5 July 1989

Dr. H.Oxlund

Department of Connective Tissue Biology

Institute of Anatomy

University of Aarhus

DK-8000 Aarhus C

Denmark 